Original Article

\title{
Spirituality in the Context of Acceptance and Commitment Therapy (ACT)
}

\author{
Kübra Kaplaner ${ }^{1}$ (이 \\ Marmara University
}

\begin{abstract}
In order to define the future, it is seen that the psychological support approaches that return to the past are replaced by the approaches that return to the essence. As the power of change that one can find in the essence; The combination of heart, mind and spirit is emphasized. Combining ACT and spiritual practice, this association contains two important concepts: awareness and acceptance. . It is thought that integration of spirituality will contribute to the concepts presented by the Act against the inevitability of unwanted thoughts and experiences. The aim of this study is to provide a general framework for cooperation between ACT and spirituality.
\end{abstract}

\section{Keywords}

Spirituality • Acceptance and Commitment Therapy $\bullet$ Psychological Counseling

\section{Kabul ve Kararlılık Terapisi (ACT) Bağlamında Maneviyat \\ Özet}

Geleceği tanımlamak için geçmişe dönen psikolojik yardım yaklaşımlarının yerini kişinin özüne dönen yaklaşımlara bıraktığı görülmektedir. Kişinin özünde bulabileceği önemli değişim gücü olarak; kalp, zihin ve ruh birlikteliği vurgulanmaktadır. ACT ve spiritüel pratiği birleștiren bu birliktelik iki önemli kavramı barındırmaktadır. Bu kavramlar; kabul ve farkındalıktır. İstenmeyen düşüncelerin ve yaşantıların kaçınılmazlığı karşısında ACT'in sunduğu kavramlara maneviyat entegrasyonun katkı sağlayacağı düşünülmektedir. Bu çalışmada ACT ve maneviyat işbirliğine ilişkin genel bir çerçeve çizmek amaçlanmaktadır.

\section{Anahtar Kelimeler}

Maneviyat • Kabul ve Kararlılık Terapisi • Psikolojik Danışmanlık

\footnotetext{
1 Correspondence to: Kübra Kaplaner (Counseling Specialist). İsmetpaşa İlkokulu. Çorum, Turkey. Email: kkaplaner89@gmail.com

Citation: Kaplaner, K. (2019). Spirituality in the context of acceptance and commitment therapy (ACT). Spiritual Psychology and Counseling, 4, 351-358. http://dx.doi.org/10.37898/spc.2019.4.3.067
} 
Efforts to bring psychology and spirituality together are recognized as important initiatives that have survived to this day.These initiatives were shaped by the contributions of new approaches without appearing in psychology. Beginning in the second half of the twentieth century, research into the direction of transcendence beyond the material experiences of the individual has been increasingly investigated in individual aid studies (Ekşi \& Kaya, 2016 ).Understanding human nature; Psychotherapy approaches that require the experiential and intuitive nature of the individual as opposed to the mechanistic and reductionist aspect of the individual are needed (Jason, Steven \& Hayes, 2016). Acceptance and Commitment Therapy (ACT), which is one of these approaches; it is defined as a psychotherapy approach that brings acceptance and awareness to therapy and supports the survival of the individual according to their values. It can be said that ACT is the leading psychotherapy model in terms of both empirical data and prevalence among the third wave cognitive-behavioral therapies (Yavuz, 2015).

ACT, which includes awareness and acceptance-based interventions; it focuses on planning the behavior of individuals in accordance with their values and explains that efforts to reduce unwanted experiences prevent it.Ögel (2011) states that there will be no unacceptable awareness. The difference of ACT from other Aids-based therapies is that the meditation content remains weaker. Cognitive Behavioral Therapy is separated from the main point; The ACT approach reduces the intensity and frequency of any internal life (thoughts, emotions, images, impulses, hallucinations, etc.).In contrast to cognitive restructuring in cognitive behavioral intervention, ACT is critical to this method. ACT is a proven psychotherapy approach for depression, anxiety, addiction, eating disorders, schizophrenia, borderline personality disorder(Hayes,2004). In the process of Acceptance and Commitment Therapy it is attempted to create psychological flexibility with six stages or to widen the existing limited flexibility level. This lack of flexibility can be defined as psychological inflexibility(Vatan,2016).

Focusing on psychological flexibility, this model is also considered as a psychological intervention model. Six processes that contribute to psychological deformation (cognitive integration, experiential avoidance, loss of contact with moment, attachment to past and future, attachment to conceptual self, distancing from values, avoidance / escapism and impulsivity) are defined in the model (Hayes, Kirk \& Kelly, 2012).

According to ACT, the level of psychological flexibility is a factor that determines the level of mental well-being of the individual. What prevents psychological flexibility is defined as experiential avoidance. Experiential avoidance presents itself with all kinds of internal and external efforts to avoid unwanted experiences (Hayes, Strosahl \& Wilson, 2012). According to ACT, the six important elements of psychological 
flexibility are considered to be stability in terms of being present, admission, intellectual decomposition, contextual self, values and values (Yavuz,2015).

New approaches to integrating spirituality into psychotherapy to cope with a variety of problems, including cancer, include ACT. An important aspect of coping with situations such as life-threatening diseases constitutes spiritual coping. While dealing with spirituality as a coping mechanism, ACT prepares the ground for active use of beliefs in achieving therapy goals. Karekle and Constantino (2010) in their study, they examined the ACT approach in cancer and religious coping; it is seen that new therapeutic approaches such as ACT emphasize that religious coping, which is an important way to cope with life-threatening diseases, will be used more effectively and this area is a promising area.

In their study, they examined the ACT approach in cancer and religious coping; It is seen that new therapeutic approaches such as ACT emphasize that religious coping, which is an important way to cope with life-threatening diseases, will be used more effectively and this area is a promising area.

\section{Acceptance and Commitment Therapy (ACT) and Spirituality}

ACT promotes values that are an important part of the individual and the maintenance of actions dedicated to these values. It is believed that the values discussed in the context of ACT should be explained in order not to confuse the values with other concepts such as goals and desires. Values in ACT applications; thoughts, emotions and events against the persistence of a permanent and continuous direction and action, and most importantly, stability, action and connected cases that require cases. The therapy environment provides an encouraging environment where the client can clearly discuss his / her values. These values are seen in spiritual values. When the values taken into consideration by ACT are considered together with the spiritual traditions, they gain an important function (Uygur,2016).

Focusing on how life will be maintained in accordance with the values of the client during the therapy process requires the orientation of the spiritual approach to ACT practices. How to achieve a good life? and what can be done to find the meaning of life? When the questions are taken in the axis of values, it is seen that integration of spirituality into the ACT process is inevitable. The process of aid in how an individual lives his life involves interaction with spiritual approaches( Jason, 2016).

Another point where you can see the existence of ACT and Spirituality on the common ground; why are we suffering? and what can we do in the face of suffering? are questions. It is inevitable to face change, loss and death in life. Pain cannot be avoided. Pain is an inevitable part of the relationship that man establishes with 
life. The important thing is the relationship of the individual with pain(Lemon \& Nunnery,2016). Acceptance in the relationship with pain is seen both in spiritual oriented studies and ACT. In a study that demonstrates the effectiveness of acceptance; patients with panic disorder. After 60 patients with panic disorder were divided into three groups; the first group is asked to experience and accept the feelings of anxiety that may arise when delivering air enriched with carbon dioxide. The second group was asked to suppress the feelings of anxiety while the air enriched with carbon dioxide, and the third group was carried out only with the addition of carbon dioxide enriched air. In the research findings, it was concluded that the participants in the first group stated that they had less anxiety than the participants in the other two groups(Levitt, Brown, Orsillo \& Barlow,2004). In this study, participants in the first group participated in the study by listening to a ten minute record based on ACT before implementation. In ACT, it can be said that the aim is to eliminate the symptoms of anxiety and other panic disorders or to create opportunities with acceptance to make the most important thing in life rather than reducing pain.

ACT and spirituality intersect in the common field of human struggle for reducing suffering. Spirituality and ACT explain that trusting in a transcendent being to ease the pain will facilitate the acceptance of pain. When we look at the researches based on spirituality based on trust in the existence of love; Those who report that they are close to God experience less psychology stress and less loneliness and depression (Rogers, Steen \& Mcgregor, 2013).

From ACT perspective, it is seen that in a therapeutic study, transcendence, infinity and commitment can be effective in experiencing pain. One of the points that unites ACT and spiritual practice is the concept of Awareness. It is seen that awareness, which is one of the basic elements of ACT, has a positive contribution to mental health (Connell, 2009). Mindfulness, discussed in ACT and Spirituality, is considered to be Awareness based on a sense of transcendence beyond our usual or ordinary understanding of everyday life. ACT and Spirituality Encourage man to develop his potential for meaning in pain rather than coping with pain. ACT also treats numerous techniques of emotional pain as a means of value to add meaning to life. It is pointed out that in the approaches where spiritual resources are used, understanding and pain should be evaluated in a way despite the pain. Emphasizes the need to adopt inevitable pain in a positive way (Özdoğan, 2005). The evaluation made at this point reveals that the ACT perspective is not very different from spirituality. ACT; it opposes the conventional approach, where pain is bad, can be stopped and stopped. Because there may be situations in which pain will not disappear completely. In this case, the question of what happens when the painful situation does not disappear. Search for answers by Frankl What to do when there is nothing to do? The existential search may be conceivable (Ekşi \& Okan, 2017). However, ACT does not claim to 
give an existential answer to this question, but merely acknowledges that pain is an inevitable experience. It allows human experiences, including suffering, to act in accordance with one's values. In the process of ACT, spirituality opens up a wide door.

New approaches to integrating spirituality into psychotherapy to cope with a variety of problems, including cancer, include Acceptance and Commitment Therapy. An important aspect of coping in situations such as life-threatening diseases is spiritual coping. While dealing with spirituality as a coping mechanism, ACT prepares the ground for active use of beliefs in achieving therapy goals. At this point, it cannot be denied that $\mathrm{ACT}$ is a major cause for the integration of spiritual coping into therapy.

Tanhan (2014) explains that the basic principles of ACT are in line with the principles of Islam. Moreover, it is reported that Muslims living abroad avoid avoiding psychological support with the concern that they cannot be understood. In conceptualization, it is important to realize whether the client brings the spiritual or religious aspects to the therapy. Cashwell et al. (2013) in their work, they stated that many counselors did not give enough importance to the religious / spiritual aspect of the client in case conceptualization.

\section{Discussion}

This being human is a guest house.

Every morning a new arrival.

A joy, a depression, a meanness, some momentary awareness comes as an unexpected visitor.

The dark thought, the shame, the malice, meet them at the door laughing, and invite them in.

Be grateful for whoever comes, because each has been sent as a guide from beyond.

Mevlana's guesthouse poem mentioned above is one of the accepted examples (Tanhan,2014). This poetry depicts the human nature with the depiction of the guesthouse, which includes the teachings of psychotherapy, especially ACT. As it is stated, the human part is a guesthouse; good and bad have to accept everything that touches life by experiencing all life experiences. The principle of acceptance is that one must have compassion, love and respect for events and for himself. In 
this way, it is expected that the paradox of strengthening fear caused by experiential avoidance will be carried out in order to fulfill the function of life in the life of what is accepted (Ak, Eşen \& Özdengül, 2014). The transition to this paradox in the process of psychotherapy was realized by the admission of therapy into therapy. Acceptance in ACT applications; it is considered one of the components that provide psychological flexibility and acceptance in Mevlana's guest poetry is one of ACT's basic concepts (Flaxmann, Blackledge \& Bond, 2011).

In the West, there is a new tendency to integrate spirituality into consulting areas. This tendency is dealt with in the western literature in relation to managing the power of one's spiritual world. Integrating the concepts and practices of psychology with the practices and concepts of spiritual disciplines refers to the integration of spirituality into the counseling process (Hayes et al, 2012). In the literature, Maslow contributes to the concept of self-realization; When individuals are able to carry to the peak of transcendence in self-realization or when they provide spiritual satisfaction, there is a view that self-realization can be fully realized. Self-realization is much more than enjoying the fruits of the material world (Lemon \& Nunnery, 2010). It is important that the individual is aware of the power related to his spiritual resources in realizing himself. In this respect, it is thought that the basic six process of ACT opens an important door for evaluating the use of spiritual power in the therapy environment.

Jacobs (2010) state that individuals are associated with an invisible spiritual flow. Therefore, the importance of using the power of this spiritual flow in mental health studies is mentioned. The relevance of the psychic flow that embraces the notion of transcendence is thought to be used as a means of facilitating the acceptance of the undesirable experiences of the individual in many areas.

The integration of spirituality into psychotherapy approaches as a facilitator of awareness becomes important because it facilitates the client to address the situation that is now and here within the framework of the principle. The basic assumption It is thought that Acceptance and Commitment Therapy which is Awareness, will make a significant contribution to the use of spirituality or transcendence in therapy. The concept of awareness is considered to be directed towards close experience, as well as the adoption of an open, accepting attitude. It is seen that psychological aid approaches that go back to the past to define the future are replaced by approaches that return to the person's essence. Many psychotherapy approaches emphasize the self-awareness of the client and emphasize the association of heart, mind and spirit. At this point, it is thought that Acceptance and Commitment Therapy will facilitate the integration of spirituality into mental health studies. 


\section{References}

Ak, M., Eşen, E., Özdengül, F. (2014). Mevlana Penceresinden Bilişsel Terapiler. Bilişsel Davranışçı Psikoterapi ve Araştırmalar Dergisi.3,133-141.

C, Hayes. (2004).Acceptance and commitment therapy, relational frame theory, and the third wave of behavioral and cognitive therapies. Behavior Therapy. 35(4):638-65.

Connell, O. (2009). Introducing mindfulness as an adjunct treatment in an established residential drug and alcohol facility. The Humanistic Psychologist, 37, 178-191.

Flaxman, P. E., Blackledge J.T., \& Bond, F. W. (2011). Acceptance and commitment therapy: The CBT distinctive features series. New York, US: Routledge/Taylor\&Francis Taylor.

Ekşi, H.,Kaya, Ç. (Ed.) (2016).Manevi Yönelimli Psikoterapi ve Psikolojik Danışma.İstanbul, KaknüsYayınları.

Ekşi, H.,Okan, N. (2017).Logoterapi ve maneviyat ilişkisi. Ekşi, H.(Eds.),Psikoterapi ve psikolojik danışmada maneviyat kuramlar ve uygulamalar kitabı içinde(s,163-189).İstanbul: Kaknüs Psikoloji.

Harris, R. (2016). ACT’i kolay öğrenmek.(Karatepe, T.A. , Çev.).İstanbul: Litera Yayıncılık.

Hayes, S.C., Vilatte, M., Levin, M. (2011). Open, Aware, and Active: Contextual Approaches as an Emerging Trend in the Behavioral and Cognitive Therapies. Annu. Rev. Clin. Psychol. 7,68-141.

Hayes, S. C., Smith, S. (2005). Get out of your mind and into your life: The new acceptance and commitment therapy. CA: New Harbinger.

Hayes,S.C., Strosahl, K., Wilson, K.G. (2012).Acceptance and commitment therapy: An experiential approach to behavior change. New York: Guilford Publication;

Hayes, S. C. (2005). Get out of your mind \& into your life: A new acceptance \& commitment therapy.CA: New Harbinger Publications.

Hayes, S.C.,Kirk, D.,Kelly, G.W. (2012). Psychological flexibility as a unified model of human functioning.In Hayes, S.C., Kirk, D., Kelly, G.W. (Eds.), Acceptance and Commitment Therapy: The Process and Practice of Mindful Change (pp.61-99). New York: Guilford Publication

Jacobs, S.T. (2010). Mindfulness and the 12 steps. Center City, MI: Hazelden.

Jason,A., Steven, N., C. Hayes (2016). ACT for Clergy and Pastoral Counselors. Kanada:Raincoast Books.

Karekla,M., Constantinou, M. (2010). Religious Coping and Cancer: Proposing an Acceptance and Commitment Therapy Approach. Cognitive and Behavioral Practice.17,371-381.

Lemon,C.J., Nunnery, R. (2016). Integrating Spirituality, Embodying Religiosity, and Promoting Ego Transformation: A Transpersonal Psychology Approach to Mindfulness, Acceptance, and Values Formation.This Paper is Part of annual VISTAS Project sponsered by the American Counseling Association.http://www.counseling.org/knowledge-center/vistas.

Levitt, J.T., Brow, T.A., Orsillo, S.M. \& Barlow, D.H.(2004) .The Effect Of Acceptance Versues Suppression Of Emotion On Subjective And Psychophysiological Response To Carbondioxide Challange İn Patiets With Panic Disorder.Behavior Therapy.35,747-766.

Ögel, K. (2011). Farkındalık ve Kabullenme Temelli Terapiler. Ankara: Hekimler Yayın Birliği.

Özdoğan, Ö. (2005). Ruhsal Yaklaşım ve İnsan Türkiye'de Bir Uygulama Örneği. Tasavvuf: İlmî ve Akademik Araştırma Dergisi. 15(6), 137-152.

Rogers, S. A., Steen, L., \& McGregor, K. (2013). Acceptance. D. F. Walker \& D. L. 
Tanhan, A. (2014). Spiritual strength: the use of Acceptance and Commitment Therapy with Muslim clients (Unpublished master's thesis). University of Rochester, Rochester, NY.

Uygur, A.E. (2016). Değerler Sisteminin(Dini Başa Çıkma, Affedicilik ve Emmons Şükür Ölçekleri Açısından) Anksiyete Duyarlılığı Üzerindeki Yordayıcı Etkisi: Metakognisyonların Aracı Rolü. Üsküdar Üniversitesi, Sosyal Bilimler Enstitüsü,İstanbul.

Vatan, S. (2016). Third Wave of Cognitive Behavioral Therapies. Current. Approaches in Psychiatry.8(3),190-203 doi: 10.18863/pgy.238183

Yavuz, F. (2015). Kabul ve Kararlılık Terapisi (ACT): Genel Bir Bakış. Turkiye Klinikleri J Psychiatry-Special Topics.8(2), 7-21. 